ЯНИЦКИЙ Олег Николаевич - доктор философских наук, профессор, главный научный сотрудник Института социологии Федерального центра теоретической и прикладной социологии Российской академии наук (117218, Россия, г. Москва, ул. Кржижановского, 24/35, корп. 5; oleg.yanitsky@ yandex.ru)

\title{
ДИСКУССИЯ ПО ПРОБЛЕМАМ ГЛОБАЛЬНОЙ БЕЗОПАСНОСТИ
}

Аннотация. В статье сопоставляются несколько подходов к проблеме глобальной безопасности: Римского клуба, англосаксонской экономико-политической элиты, российских военных специалистов и нового поколения российских и международных экоглобалистов. Показывается, что целью англосаксонской элиты является сохранение однополярного мира, при котором проблемы бедности и избытка населения перестанут быть актуальными. Кратко рассматривается ситуация с гражданской обороной. $B$ заключение дается характеристика нового поколения экоглобалистов, практикующих инсайдерский подход и междисциплинарный анализ.

Ключевые слова: безопасность, военная наука, глобализация, однополярный мир, Римский клуб, новые экоглобалисты

Э та дискуссия продолжается уже более полувека, начиная с Первого доклада Римскому клубу. Сейчас она снова активизировалась, тем более что этот международный клуб выдающихся политиков, предпринимателей и ученых в 2018 г. празднует свое пятидесятилетие [Von Weizsäcker, Wijkman 2018].

В серии докладов Римскому клубу его участники акцентировали внимание политиков и ученых прежде всего на необходимости замедления роста народонаселения планеты со всеми вытекающими отсюда последствиями, и в первую очередь с сокращением потребления всех видов ресурсов. Соответственно, произошло бы сокращение загрязнения всех сред биосферы, а следовательно, сократился бы и «парниковый эффект», создаваемый ее загрязнением, и т.д. Но у данной проблемы есть другая сторона: конкуренция и борьба глобальных сил (или тех, кто считает себя таковыми) за право устанавливать глобальный экономический и социальный порядок. То, что члены Римского клуба сегодня называют «близоруким капитализмом», - верно, но совершенно недостаточно. Ставки гораздо выше: или сохранить человечество и его среду обитания, биосферу, или же создать замкнутый мир «продвинутых и богатых», а оставшиеся природа и люди пусть выживают сами. То есть, мир и демократия только для избранных.

\section{Доктрина однополярной глобализации и ответ на нее}

Англосаксонский Запад всеми силами продвигает эту доктрину, несмотря на растущее сопротивление ей как в развивающихся, так и в наиболее развитых странах. Поэтому международная напряженность с каждым днем усиливается, число и география «простых» и гибридных войн локального характера возрастает. Явно прослеживается тренд англосаксонского мира к восстановлению былой глобальной гегемонии, а значит к сохранению и расширению глобальной модели общества потребления на одном полюсе и консервации бедности и бесправия - на другом.

Новое в этой стратегии и тактике США и их союзников - это использование информационно-коммуникационных технологий для «размягчения» сознания вероятного противника, а затем и его подчинение целям глобализации по-американски. Но это только первый этап, за которым должны последовать реальные силовые действия по подчинению «третьего мира» принципам и пра- 
вилам мира англосаксонского. Не следует думать, что за этой доктриной однополярной глобализации не стоят объективные причины. Напротив, ее идеологи апеллируют к тем же реальным угрозам: бедности и безработице, перенаселенности планеты, вооруженным, в т.ч. межэтническим, конфликтам, нехватке воды и пищи, к тому же глобальному изменению климата и т.д.

У этой англосаксонской идеологии мирового господства есть три принципиальных отличия. Во-первых, сначала этот блок стран силовым образом устанавливает свой миропорядок, а уже потом будет думать, как решать названные и другие проблемы. Тем самым он фактически признается, что экологические и социальные проблемы, в т.ч. проблема бедности, подождут. Во-вторых, уже идущая четвертая промышленная революция сделает просто ненужным такое количество населения - основную работу будет выполнять робототехника [Шваб 2017], и тогда население планеты начнет сокращаться само по себе. Есть и более «деликатная» точка зрения: людей, потерявших работу, мы, богатые страны, возьмем на содержание - это нам проще и дешевле, чем создавать для них рабочие места, обучать и переучивать их и т.д. В подготовке к этому новому миропорядку немалую роль играют массмедиа с их настойчивой пропагандой необходимости непрерывного роста потребления и, в частности, готовых «стилей жизни»... И вообще - не надо ни за что бороться, наслаждайтесь тем, что мы вам уже дали. И рожать детей вовсе не обязательно, тем более если некий индивид сегодня мужчина, а завтра - женщина. В-третьих, англосаксонский мир вернулся к идеологии устрашения, уже начав новую гонку вооружений, в т.ч. перенося ее в космическое пространство.

В российских массмедиа идет дискуссия о том, является ли это ли новой «холодной войной» или еще только прелюдией к ней. И как Россия должна отвечать на этот глобальный вызов? Пока, однако, кроме вполне адекватной дипломатической войны и жарких публичных дискуссий в РФ с соблюдением всех правил демократического приличия (борьба точек зрения, слово нашим оппонентам и т.д.), концептуального ответа на этот глобальный вызов пока не просматривается. По факту Россия уже включилась в гонку вооружений, тоже космических. Каждое ведомство - экономическое, экологическое или другое уже заранее создало доктрину развития своего ведомства, которые, естественно, корректируются, уточняются по ходу дела. Но, подчеркиваю, общего концептуального ответа на этот глобальный вызов у нас нет, потому что сумма отраслевых доктрин не является интегративной глобальной концепцией ответа на него. И демонстрации мощи отдельных видов военной техники здесь недостаточно. А что думают сами военные и силы МЧС? Социологи и другие обществоведы нечасто заглядывают в соответствующую литературу. Попытаюсь частично восполнить этот пробел.

\section{«Горячие точки науки»}

Это название придумал не я - так называется программная статья, подготовленная Генштабом вооруженных сил РФ совместно с Академией военных наук [Герасимов 2018: 1-2]. Но я говорил и повторяю, что за последние 10-15 лет военные специалисты и сотрудничающие с ними обществоведы уделяют глобальной проблематике как сложному, междисциплинарному феномену гораздо большее внимание, чем сами традиционные обществоведы [Яницкий 2014]. Ниже идет краткое изложение основных проблем, реакции на которые военные ждут от научного сообщества.

Во-первых, в ответ на попытки глобального диктата в мире «резко активизировалось межгосударственное противоборство, основу которого составляют невоенные меры - политические, экономические, информационные». Это 
противоборство распространилось на все виды иной деятельности - дипломатическую, научную, спортивную. Во-вторых, под лозунгом сохранения мира и распространения демократии попираются общепринятые нормы международного права.

B-третьих, «прослеживается тенденция исчезновения границ между миром и переходом в состояние войны». Я уже неоднократно отмечал, что сегодня дихотомическая методология типа «мир или война», «фронт или тыл», «мы или они» уже не работает. Не случайно поэтому военные специалисты акцентируют значение «сплошного радиолокационного поля» вдоль всех границ РФ как необходимого условия обороны от внешнего врага. Тотальное «поле противоборства» требует тотальных средств перманентного наблюдения и защиты. Поэтому социологии сегодня нужны средства сплошного и непрерывного мониторинга, а не квотные выборочные исследования раз от раза.

В-четвертых, фактор времени становится ключевым условием успеха. Возрастает пространственный размах военных действий, повышаются их напряженность и динамичность. Происходит переход от последовательных и сосредоточенных действий к их непрерывным и распределенным формам, проводимым одновременно во всех сферах противоборства» - как на ближних, так и на дальних участках театра военных действий. Социологи и политологи перестали исследовать этот аспект нашего благополучия и безопасности.

B-пятых, современная война - это сетевая война, включающая как продолжительную бесконтактную, т.е. сетевую, борьбу, так и мощную, но короткую по времени фазу наземных контактных действий. Такая смена темпо-ритмов военного или иного противоборства - характерный признак «гибридной войны». В-шестых, одним из приоритетов современности является «разработка современных средств управления и связи, интегрированных в единое информационное пространство» (курсив мой. - О.Я.). К сожалению, я не знаю работ моих коллег, изучающих это пространство.

В седьмых, требования к военным и гражданским руководителям повышаются. «Особое внимание уделяется выработке у командиров всех степеней способности к быстрым и всесторонним обоснованным действиям». Что это значит? В частности, это означает развитие навыков «принятия нестандартных решений, развиваются способности к прогнозированию обстановки, решительным действиям, оправданному риску», что, как очевидно, контрастирует с поведением сил МЧС и других подразделений строго в соответствии с инструкциями. Это требование современной обстановки вовсе не противоречит задаче создания автоматизированных систем сбора и анализа информации и совершенствования «структуры органов управления». Но не ручного, к чему мы привыкли сегодня, а автоматизированного управления как военными, так и гражданскими действиями, о необходимости чего еще в 1960-х гг. прошлого века писал выдающийся русский ученый академик АН СССР В.М. Глушков.

\section{Расхождения между позициями военных ученых и МЧСников}

Возьму только одну, но важнейшую проблему: безопасность мирного населения. И шлейф такого отчуждения тянется издалека, еще из середины 1950-х гг., (мне как бывшему специалисту военно-инженерных войск пришлось быть невольным свидетелем неподготовленности населения). Хотя во время той войны, да и сейчас, например, на Донбассе или в Сирии, мирное население спасается именно по подвалам. Часто слышу вопрос: почему в США строят глубинные укрытия и бомбоубежища, а у нас то, что было создано во время Великой Отечественной войны, продано под склады или увеселительные заведения? 
К сожалению, и сегодня, и 100 лет назад природа рассматривалась лишь как «поле боя» или как средство сбережения живой силы и техники. При нынешних средствах ведения войны сказанное касается и такой проблемы, как сохранение биосферы. Между тем, если эта очень сложная и тонко настроенная система будет нарушена или просто «сорвана», то никакие спасательные меры уже не помогут. На стыке этих двух задач - сбережения мирного населения и сохранения биосферы - возникает проблема соотношения настоящего и будущего. Это, на мой взгляд, сложная философская проблема, требующая специального рассмотрения.

В этой связи сошлюсь на еще одну работу военных специалистов, отмечающих отставание системы гражданской обороны, призванной в первую очередь защитить мирное население. Как пишет Ю. Шабалин, Министерство обороны не делится с рядовыми гражданами своими соображениями насчет грядущей войны. Вот лишь некоторые критические замечания, высказанные автором в адрес МЧС. Предполагаемая война будет «весьма аккуратной и компактной», «ядерные удары исключены», «воевать будут спецназовцы и никакой тебе линии фронта». «Оказывается, - пишет Ю. Шабалин, - утверждены документы, в которых национальная безопасность считается обеспеченной», и с «населением потенциальный противник воевать не будет». Это означает, что «для МЧС меньше хлопот. Не нужно бомбоубежищ, ни к чему подготовка населения, да и сама гражданская оборона». И дальше этот автор задает такие вопросы: «Многие ли сейчас знают, как, случись беда, добраться до бомбоубежища? А в каком они состоянии?.. Где-нибудь приготовлено жилье для эвакуированных, кто-то о них позаботился?» Многие ли знают, как надеть противогаз? Знает ли население, что хватать в первую очередь, если придется срочно покинуть дом? И т.Д. [Шабалин 2018: 1, 5].

Если к этому прибавить, что в прошлую эпоху метро строили глубокого заложения, что бомбоубежища сохранялись после ВОВ еще не менее 10-16 лет, а современный школьный курс ОБЖ не включает изучение названных выше и многих других вопросов, то картина получается довольно печальная. Шабалин цитирует слова генерала Л. Ивашова: «Экономика, наш тыл, не может поддержать военных действий», а значит и сберечь мирное население.

Но и это не все. Глобальная безопасность не ограничивается снижением международной напряженности и ростом взаимного доверия. Атака на нашу землю из космоса - исторический факт и возможное будущее. Как пишет К. Сивков, человечеству надо всерьез готовиться к отражению атаки из космоса. То есть, речь идет о риске тотального разрушения земли космическим телом или посредством иного, но столь же разрушительного воздействия. Но какой же тогда должна быть эта оборона? Очевидно, пишет этот автор, «она должна быть интернациональной, без привязки к какому-либо государству вне зависимости от его вклада в создание противоастероидного оружия. По этой причине в системе управления ею не может быть людей, которые связаны корыстными материальными интересами или узко государственными приоритетами... Должны быть также исключены представители любых транснациональных структур». Но кто же тогда? Название этого параграфа говорит само за себя: «Вся власть ученому совету» [Сивков 2018: 9], т.е. коллективу ученых мирового уровня и соответствующему ему инженерному персоналу.

\section{Новое поколение экоглобалистов}

Их вклад в понимание современной ситуации заслуживает специального рассмотрения. Поэтому здесь изложу мое видение этого нового поколения, тем более что дискуссия между ними продолжается. Но сначала: кто они? Это моло- 
дые высокообразованные люди самых разных специальностей из России, стран СНГ, но не только. Многие из них были раньше членами дружин охраны природы или Социально-экологического союза [Yanitsky 2000]. Они члены международной сети междисциплинарной коммуникации между самыми разными специалистами; многих из них я раньше знал лично.

Что их объединяет? Это гражданские активисты, многие из которых сотрудничали ранее или продолжают сотрудничать как с государственными структурами, так и с самыми разными НКО. Но главные их качества - это то, что они бывалые люди и придерживаются гражданской позиции инсайдеров, то есть людей, непосредственно включенных в природоохранные процессы и социальную, экономическую и экологическую политику. В отличие от концепции авторов множества докладов Римскому клубу, акцентировавших проблему пределов роста человечества, это новое поколение критикует современных теоретиков глобальной безопасности за попытки смоделировать эту задачу, манипулируя всего двумя параметрами: экономическим и демографическим состоянием общества, т.е. только социальными аспектами, практически исключая из своих моделей такой ключевой фактор, как состояние самой биосферы (среда обитания) и ее реакция на все внешние факторы. Между тем, как я уже неоднократно отмечал, среда обитания - тоже агент социальных и других изменений, и она имеет предел своей несущей способности. Более того, биосфера под воздействием человека быстро превращается в социобиотехносферу (СБТ-систему) [Яницкий 2016], закономерности которой еще недостаточно изучены. Как справедливо отмечают эти новые экоглобалисты, решить задачу сохранения биосферы нельзя, изучая только энергетические и информационные потоки. Эти активисты, конечно, не рассматривают случаи вооруженного противостояния, но они весьма внимательны ко всем другим формам борьбы между государствами или их блоками, включая политическое и финансовое давление, поскольку их совокупность, как показывает практика, может дать разрушительный эффект, сравнимый с военными действиями.

\section{Выводы}

Сегодня рассуждать о проблемах экологии вне глобального военно-политического анализа невозможно. Это означает, что динамика сложившейся в мире ситуации требует междисциплинарного анализа и всеобъемлющего мониторинга. Особое беспокойство вызывает позиция организаций, ответственных за гражданскую оборону, за спасение людей в случае войны, природных и техногенных катастроф. Формирование в последнее десятилетие нового поколения экоглобалистов дает надежду, что проблема глобальной безопасности будет решаться параллельно с охраной окружающей среды.

\section{Список литературы}

Герасимов В. 2018. Горячие точки науки. - Военно-промышленный курьер. № 12 (725). C. 1-2.

Сивков К. 2018. 56 армагеддонов. - Военно-промышленный курьер. № 7(720). C. 1,9 .

Шабалин Ю. 2018. Эвакуированные в светлое будущее. - Военно-промышленный курьер. № 9(722). С. 1, 5.

Шваб К. 2017. Четвертая промышленная революция. М.: Изд-во «Э». 208 с.

Яницкий О.Н. 2014. Социология критических состояний общества. Социологическая наука и социальная практика. № 4(8). С. 5-24.

Яницкий О.Н. 2016. Социобиотехнические системы: новый взгляд на взаимо- 
действие человека и природы. - Социологическая наука и социальная практика. T. 4. № 3. C. 5-22.

Von Weizsäcker E.U., Wijkman A. 2018. Come On! Capitalism, Short-termism, Population, and the Destruction of the Planet. Springer. $220 \mathrm{p}$.

Yanitsky O. 2000. Russian Greens in a Risk Society. A Structural Analysis. Helsinki: Kikimora Publications.

YANITSKY Oleg Nikolaevich, Dr.Sci. (Philos.), Professor, Chief Researcher of the Sociological Institute - branch of the Federal Center of Theoretical and Applied Sociology, Russian Academy of Sciences (bld. 5, 24/35 Krzhizhanovskogo St, Moscow, Russia, 117218; oleg.yanitsky@yandex.ru)

\title{
DISCUSSION ON GLOBAL SECURITY ISSUES
}

\begin{abstract}
The aim of the article is to compare several approaches to an issue of current global safety developed by various global agents, namely by the modern representatives of the Club of Rome, by the leading stakeholders of the Anglo-Saxon economic and political elite, by the representatives of Russian military science and that of the activists of new generation of Russian and international eco-globalists. Judging by the last report to the Club of Rome (2018), its authors still remains on the position of the limits to growth. The modern Anglo-Saxon elite tried to maintain their leading positions in the shaping of global social order and technological development. The Russian military elite comes out for a multipolar world based on multisided talks and agreements and at the same time stresses an importance of civil defense and the development of solid scientific base of strategy and tactics of Russian armed forces. The author considers new generation of international ecoglobalists practice, which use an insider approach and interdisciplinary analysis in their work.
\end{abstract}

Keywords: civil defense, elite, global safety, globalization, military science, safety, technological development 